\title{
MEASUREMENT OF ULTRASONIC VELOCITY IN SEVERAL BIOLOGICAL TISSUES
}

\author{
L. A. Frizzell and J. D. GINDORF \\ Bioacoustics Research Laboratory, University of Illinois, Urbana, IL 61801 , \\ U.S.A.
}

(First received 18 June 1980; in final form 13 November 1980)

\begin{abstract}
The ultrasonic velocity at $100 \mathrm{MHz}$ and room temperature $\left(23-26^{\circ} \mathrm{C}\right)$ was measured in fresh, excised mammalian liver, kidney, spleen, and pancreas and mouse kidney. The results show excellent agreement with measurements at low $\mathrm{MHz}$ frequencies. A significant velocity difference is reported between kidney cortex and medulla, but no difference was observed between the exocrine and islets of Langerhans in the first measurements of velocity in the pancreas.
\end{abstract}

\section{INTRODUCTION}

The scanning laser acoustic microscope has been shown to be a valuable tool for imaging both biological and non-biological materials (Eggleton and Kessler, 1975; Kessler and Yuhas, 1979). Information on the elastic properties of specimens at $100 \mathrm{MHz}$ and higher frequencies is provided through two types of acoustic modes. The acoustic image is formed due to variations in the attenuation while the acoustic interferogram reveals any variations in velocity within the sample. These two modes of operation have also been employed to measure the attenuation coefficient and velocity in biological materials (Kessler et al., 1974a,b; Eggleton and Vincent, 1979; Yuhas and Kessler, 1979; Goss and O'Brien, 1979). The attenuation coefficient increases nearly linearly with frequency over the range of frequencies employed with clinical ultrasound. Additionally, data indicate that the dependence of the attenuation coefficient on frequency at frequencies substantially above the clinical range is greater than linear (Kessler 1973). These factors combine to make the measurements of the attenuation coefficient at $100 \mathrm{MHz}$ of little direct value to the clinical application of ultrasound, though the importance indirectly through contributions to the understanding of attenuation, scattering and absorption processes in tissue should be quite significant. On the other hand, ultrasonic velocity measured at $100 \mathrm{MHz}$ seems to be approximately equal to that measured at lower frequencies (Kessler, 1974; Yuhas and Kessler, 1979; Goss and O'Brien, 1979). Several measurements of ultrasonic velocity at $100 \mathrm{MHz}$ were made on tissues previously measured only at lower frequencies. The results, reported herein, provide further confirmation of the agreement between low and high frequency measurements. Other measurements were made that provide data on some tissue structures for which data have previously been limited or nonexistant.

\section{METHODS}

Velocity measurements in fresh biological tissues were made at $100 \mathrm{MHz}$ and room temperature $\left(23-26^{\circ} \mathrm{C}\right)$ using a scanning laser acoustic microscope (Sonomicroscope 100, Sonoscan Inc., Bensenville, IL). The procedures applicable to velocity measurements using the microscope are provided in greatest detail by Goss and O'Brien (1979). Briefly the velocity is determined by detecting variations in the acoustic index of refraction using the interference mode of the microscope. A specimen of known thickness is placed on the fused silica stage and covered with a mirrored cover slip so that the field of illumination includes all or part of the specimen plus an area where only reference medium $(0.09 \%$ saline in this study) exists. The ultrasound is incident from the stage at an angle of $45^{\circ}$ with respect to the normal, is refracted in the specimen or reference liquid in various portions of the field, and is then incident on the mirrored surface of a cover slip. The acoustic disturbance of this surface causes angular modulation of an obliquely incident laser beam providing, via a detector, an electrical output proportional to the acoustic amplitude. In the interference mode the detected signal 
is electronically mixed with an electrical reference signal to produce interference fringes on the monitor. If a medium of uniform velocity and thickness covers the displayed portion of the field (an area approximately $2 \times 3 \mathrm{~mm}$ ), then the interference fringes are straight vertical lines. If the velocity or thickness of the medium varies in the displayed portion of the field then interference lines are displaced horizontally in one region with respect to the other. By measuring the normalized lateral fringe shift of the interference lines and using the thickness of the specimen (same as the reference medium), it is possible to determine the velocity in the unknown (Goss and O'Brien, 1979).

Biological tissues were obtained immediately after death and stored at room temperature in physiological saline until measured, usually within $1-3 \mathrm{hr}$ after excision. Sheep liver and pig kidney, spleen and pancreas were obtained from the slaughterhouse, and cat liver and mouse kidney were obtained from animals maintained in the laboratory. The tissues from the specified regions of organs were prepared for mounting on the stage by slicing them with a pair of razor blades clamped on either side of a spacer. This technique provided samples of thickness slightly greater than the thickness of the spacer. Samples were mounted on the microscope stage such that the spacer (in the shape of a washer or portion thereof) used in the slicing procedure formed a collar around the sample and reference liquid and provided a rigid support for the coverslip. The coverslip, several millimeters thick plastic, was of a weight sufficient to compress the tissue the slight amount necessary to produce a sample and reference medium of a uniform thickness equal to that of the spacer. This procedure caused minimal distortion of the tissue, and provided a means of determining sample thickness, the source of greatest error, to well within $5 \%$.

\section{RESULTS AND DISCUSSION}

The ultrasonic velocity at $100 \mathrm{MHz}$ and room temperature $\left(23-26^{\circ} \mathrm{C}\right)$ was measured for several biological structures, and the results are summarized in Table 1 . Liver tissue, for which there are a number of literature values available at lower frequencies was measured first as a check on our technique and as further verification that any difference between the velocity at $100 \mathrm{MHz}$ and that at low $\mathrm{MHz}$ frequencies is negligible. The mean values of $1565 \mathrm{~m} / \mathrm{s}$ for sheep and $1567 \mathrm{~m} / \mathrm{s}$ for cat liver agree excellently with recent measurements on beef liver $(1566 \mathrm{~m} / \mathrm{s})$ reported by Shung and Reid (1977) and early measurements by Frucht (1953) on human liver $(1569.5 \mathrm{~m} / \mathrm{s})$. The fact that literature values available on fresh liver tissue span a wide range of velocities may be partially explained by another of our observations. Of the five samples of sheep liver, three were from areas underlying the capsule while the remaining two samples included capsular tissue. The means and standard deviations of the measurements were $1559 \pm 1 \mathrm{~m} / \mathrm{s}$ and $1574 \pm 3.5 \mathrm{~m} / \mathrm{s}$, for the former and the latter tissue samples, respectively. This rather substantial difference between the velocity of these regions is in qualitative agreement with the observed dependence of velocity on collagen content (O'Brien, 1977; Goss et al., 1980a) which would suggest that a higher velocity would be observed in the higher collagen content capsular samples.

Previous studies suggest that differences may exist in the absorption coefficient between cortical and medullary structures in the kidney (Linke et al., 1973). As an attempt to determine if significant velocity differences

Table 1. Velocity in tissues at $100 \mathrm{MHz}$ and at room temperature

\begin{tabular}{llccc}
\hline Species & \multicolumn{1}{c}{ Tissues } & $\begin{array}{c}\text { No. of } \\
\text { samples }\end{array}$ & $\begin{array}{c}\text { Velocity } \\
(\mathrm{m} / \mathrm{s})\end{array}$ & $\begin{array}{c}\text { Standard } \\
\text { Deviation } \\
(\mathrm{m} / \mathrm{s})\end{array}$ \\
\hline Sheep & Liver & 5 & 1565 & 7.8 \\
Cat & Liver & 8 & 1567 & 13.2 \\
Mouse & Kidney & 22 & 1586 & 10.7 \\
Pig & Kidney-medulla & 29 & 1564 & 6.1 \\
Pig & Kidney-cortex & 28 & 1578 & 7.2 \\
Pig & Spleen & 23 & 1575 & 9.7 \\
Pig & Pancreas-exocrine & 12 & 1591 & 9.2 \\
Pig & Pancreas-islet & 12 & 1591 & 8.7 \\
\hline
\end{tabular}


exist between these two structures the mouse kidney was examined; however, it proved to be impossible to separate samples from these two regions in such a small kidney. Samples were easily separated from the pig kidney. The results show that the mean velocity measured in medullary tissue is $14 \mathrm{~m} / \mathrm{s}$ less than that found for cortical structures. This is qualitatively in agreement with the effects of greater water content, i.e. lesser protein content, of the medullary tissues (Goss et al., 1980a).

Spleen and pancreas were measured as tissues for which relatively few and no velocity measurements have been reported, respectively, (Goss et al., 1978a, 1978b, 1980). The results for spleen are in the range of previously reported data (Goss et al., 1978b, Goss et al., 1980a,b). Two distinct tissue structures were measured for the pancreas, i.e. exocrine and islets of Langerhans. These two regions exhibit rather different physical qualities. The exocrine is an inhomogeneous, soft, mushy tissue held together by a capsule, whereas the islets of Langerhans are firm, kidney shaped structures. Despite the differences in the physical appearance and firmness between the two structures the means of velocity measurements were identical for each. This contrasts with the difference observed for various kidney structures. In addition, the velocity for pancreas is highest among the results reported herein.

In summary, the acoustic microscope provides a means of measuring velocity in small tissue samples of clinical relevance. A significant difference between the velocity in kidney cortex and medulla was observed which is consistent with previously reported dependence of velocity on water and protein content. The first measurements on pancreas show that both the exocrine and islets of Langerhans structures exhibit the same velocity, which is highest among those measurements reported here.

Acknowledgements - This work was supported in part by grants from the Institute of General Medical Sciences, National Institutes of Health, and the National Science Foundation. The authors gratefully acknowledge the assistance of Professor W. D. O'Brien, Jr. and Mr. Charles Edwards.

\section{REFERENCES}

Eggleton, R. C. and Kessler, L. W. (1975) Mouse embryo heart in organ culture visualized by the acoustic microscope. In Ultrasound in Medicine (Edited by White, D. N.), Vol. 1, pp. 537-542. Plenum Press, New York.

Eggleton, R. C. and Vincent, F. S. (1977) Heart model supported in organ culture and analysed by acoustic microscopy. In Acoustical Holography (Edited by Kessler, L. W.), Vol. 7, pp. 21-35. Plenum Press, New York.

Frucht, A. H. (1953) Die Schallgeschwindigkeit in Menschlichen and Tierischen Gewenben. Z. Gesamte Exp. Med. 120, 526-557.

Goss, S. A., Frizzell, L. A., Dunn, F. and Dines, K. A. (1980a) Dependence of the ultrasonic properties of biological tissue on constituent proteins. J. Acoust. Soc. Am. 67, 1041-1044.

Goss, S. A., Johnson, R. L. and Dunn, F. (1978a) Ultrasound mammalian tissue properties literature search. Acoust. Letters 1, 171.

Goss, S. A., Johnston, R. L. and Dunn, F. (1978b) Comprehensive compilation of empirical ultrasonic properties of mammalian tissues. J. Acoust. Soc. Am. 64, 423-457.

Goss, S. A., Johnston, R. L. and Dunn, F. (1980b) Compilation of empirical ultrasonic properties of mammalian tissues-II. J. Acoust. Soc. Am. 68, 93-108.

Goss, S. A. and O'Brien, W. D., Jr. (1979) Direct ultrasonic velocity measurements of mammalian collagen threads. J. Acoust. Soc. Am. 65, 507-511.

Kessler, L. W. (1973) VHF Ultrasonic attenuation in mammalian tissue. J. Acoust. Soc. Am. 53, 1759-1760.

Kessler, L. W. (1974) Review of progress and applications in acoustic microscopy. J. Acoust. Soc. Am. 55, 909-918.

Kessler, L. W. (1978) Acoustic characterization of tissue at the microscopic level-sonohistology. In Ultrasound: Its Applications in Medicine and Biology (Edited by Fry, F. J.), Chap. XIII, Part II, pp. 673-687. Elsevier Scientific, New York.

Kessler, L. W., Fields, S. I. and Dunn, F. (1974a) Acoustic microscopy of mammalian kidney. J. Clin. Ultrasound 2, 317-320.

Kessler, L. W., Palermo, P. R. and Korpel, A. (1974b) Recent developments with the scanning laser acoustic microscope. In Acoustical Holography (Edited by Green, P.), Vol. 5. Plenum Press, New York.

Kessler, L. W. and Yuhas, D. E. (1979) Acoustic microscopy-1979. Proc. IEEE 67, 526-536.

Linke, C. A., Carstensen, E. L., Frizzell, L. A., Elbadawi, A. and Fridd, C. W. (1973) Localized tissue destruction by high-intensity focused ultrasound. Arch. Surg. 107, 887-891.

O'Brien, W. D., Jr. (1977) The role of collagen in determining ultrasonic propagation properties in tissue. In Acoustical Holography (Edited by Kessler, L. W.), Vol. 7, pp. 37-50. Plenum Press, New York.

Shung, K. K. and Reid, J. M. (1977) Ultrasonic scattering from tissues. 1977 Ultrasonics Symp. Proc., IEEE Cat. No. 77CH1264-1SU, 230-233.

Yuhas, D. E. and Kessler, L. W. (1979) Acoustic microscope analysis of myocardium. In Ultrasonic Tissue Characterization, Vol. II (NBS Spec. Publ. 525) (Edited by Linzer, M.), pp. 73-79. U.S. Government Printing Office, Washington, DC. 